\title{
ANALYSIS OF THE INTRODUCTION OF BUSINESS INTELLIGENCE AND DATA WAREHOUSING INTO BUSINESSES IN LATVIA
}

\author{
Janis Birznieks¹, Mg.oec.; Lasma Licite-Kurbe², Dr.oec., associate professor
}

\author{
1, 2 Latvia University of Life Sciences and Technologies
}

\begin{abstract}
The market of global business intelligence technologies reached EUR 18.3 billion in 2017 and is expected to reach EUR 22.8 billion in the near future, as such technologies provide companies with a number of benefits: new information for business decision-making, real-time financial reporting and manual work automation. Nevertheless, many companies around the world do not achieve the desired results of applying business intelligence and data warehousing technologies. The research aims to develop scenarios for applying business intelligence and data warehousing tools in entrepreneurship in Latvia based on an examination of the tools. The research has found that the companies examined in the case study have introduced business intelligence along with data warehousing; however, there are differences in applying the business intelligence and the level of its advancement. Overall, a business intelligence system makes core and support operations and processes faster, as well as reduces costs and requires less human resources. However, problems were identified concerning a lack of motivation in employees to learn new technologies. The scenario analysis concluded that large companies should perform as many administrative and technological processes related to the mentioned technologies as possible themselves rather than outsource them, which allows them to save funds on the development of such technologies and improve the company's data culture.
\end{abstract}

Keywords: business intelligence, data warehouse, IT architecture.

JEL code: $\mathrm{C} 8, \mathrm{O} 33, \mathrm{O} 3$

\section{Introduction}

Information technology and data availability become increasingly important for successful business. Business intelligence is a term that refers to technologies and processes for effective data collection, storage and analysis (Presthus W., Stian S., 2015). International experience shows that introducing and applying effective business intelligence also requires a data warehouse - an aggregated database containing data from several external and internal data sources. Such technological solutions provide companies with several benefits: new information for business decision making, real-time company financial reporting (Bach M. P. et al., 2016), as well as manual work automation, thereby releasing human resources for more important analytical work (Kimball R. et al., 2006., Larson D., Chang V., 2016).

The market of global business intelligence technologies reached EUR 18.3 billion in 2017 and is expected to reach EUR 22.8 billion in the near future (Ain N. et al., 2019). Nevertheless, many companies in the world do not achieve the desired results of applying business intelligence and data warehousing technologies, and there are conflicting views on this problem in the industry examined. A number of scientific research studies have been conducted worldwide on the effects of data analytics and information systems on business. Ain et al. (2019) have identified various challenges for the introduction of such technologies, as well as the areas where more research is needed. K. Bozic and V. Dimovski (2019) have found a positive link between business intelligence application by a company and the performance of the company. In Latvia few researchers focus on business intelligence (Disteina I., 2019; Ezerins I., 2009; Peskops M., 2017). However, there is a general lack of research on the willingness of end users of such technologies to use the tools on a daily basis, as well as on the users' knowledge of the information technologies required for the tools to be used. Most of the research studies focus on the technological aspects of business intelligence and data warehousing, yet it is important to examine how the technologies are applied by the end user and what factors affect the applications (Ain N. et al., 2019). Given the

1 E-mail address: janis234@gmail.com 
relevance of the topic, the research did an assessment of the introduction of business intelligence and data warehousing by businesses in Latvia.

Research hypothesis: introducing a business intelligence information system and data warehousing into a company is more economically advantageous if using only human resources available in the company.

Research aim: to develop scenarios for applying business intelligence and data warehousing tools in business in Latvia based on an examination of the tools. The following specific research tasks were set to achieve the aim: 1) to give insight into the theoretical aspects of business intelligence and data warehousing; 2) to perform a case study on the experience of companies in their introduction and application of business intelligence and data warehousing; 3 ) to develop scenarios for the introduction and implementation of business intelligence and data warehousing in companies.

A number of research methods were employed to do the research: monographic and descriptive for theoretical discussion and interpretation of the research results based on scientific findings and theories; analysis and synthesis for examination of problem elements and identification of regularities; induction for making assumptions based on individual elements or facts; deduction for logical systematization and interpretation of empirical data. To gain an in-depth understanding of the application of business intelligence and data warehousing in business in Latvia, a case study was performed on the SJSC Real Estate and the JSC Latvian State Forests. The scenario method was used to identify scenarios for the introduction and implementation of business intelligence and data warehousing, highlighting the benefits and challenges of each scenario. Expert interviews were conducted to determine the most appropriate scenario.

The present research used the following information sources: research papers of international scientific journals, electronically available national and foreign periodicals focusing on business intelligence and data warehousing.

\section{The essence and role of business intelligence}

The concept of business intelligence refers to strategies and technologies for storing, managing and analysing various company data (Harrison R. et al., 2015). According to W. Presthus and S. Stian (2015), business intelligence is a generic term that refers to technologies and processes related to data collection, storage and analysis with the aim of helping a company to make right business decisions. B. Raza et al. (2020) regards a data warehouse as a database containing historical information about the organization that serves as a central place to store data for analysis and processing purposes.

Most often, business intelligence technologies perform the following functions: company financial performance analysis and business process management, data mining, predictive analysis of various indicators and reporting on core business and support processes (Bozic K., Dimovski V., 2019). However, there are other ways whereby business intelligence reporting can help a company: descriptive analytics (data analysis that can explain a particular phenomenon), data query generation, statistical analysis, data visualization, visual analysis, and data preparation for other purposes.

Business intelligence could be used also for creating non-standard applications and solutions. Most business intelligence solutions provide interactive visualizations that allow the user to view the data they want broken down by a variety of dimensions. However, if some user or business intelligence specialist has a good knowledge of a particular solution, s/he can program a solution needed, e.g. for pay or bonus calculations, instead of doing regular reporting, thereby gaining a new knowledge (Wieder B., Ossimitz M. L., 2015) and projecting the development of a specific area (Grubljesic T., Jaklic J., 2015). W. Presthus and S. Stian (2015) emphasize in their research that business intelligence is useful in various 
industries, incl. health, entertainment, nature protection and manufacturing. In addition, a business intelligence solution or application is not just a tool for the company's business analysts or IT specialists, and it could also be used by other employees of the company for their daily work. Of course, the employee needs knowledge of the specific solution to make full use of the opportunities provided by this solution.

A business intelligence system can help a business to gain the upper hand over its competitors in terms of information. It can help a company to generate and gather new information needed for making business decisions (Bozic K., Dimovski V., 2019). However, for a company to successfully use the advantages, it needs a range of specialized knowledge and technology that is not available to all companies (Larson D., Chang V., 2016). To make full use of business intelligence, a company needs data to analyse. For companies that do not have such data or the data are of poor quality, value added from business intelligence might be insignificant (Kimball R. et al., 2006). However, the introduction of such technologies could be a good motivator to structure the available data in the company or develop current information system projects, considering the introduction of business intelligence and data warehousing technologies in the future.

To successfully introduce business intelligence together with data warehousing into a company, it is required to effectively combine the understanding of business processes with information technologies. Business experts need to understand what business intelligence can do, while IT professionals need to understand what the needs of business experts are and how to meet them. The costs of introducing new information systems should also be taken into account. It is important for company managers to assess whether the company is capable of introducing such complex systems. Large-scale information system projects often spend $45 \%$ more funds, $7 \%$ more time and generate up to $56 \%$ less end value than initially planned (Bloch M. et al., 2012). There are also research studies that have found that the ability of a company to introduce its own specialized information systems might not positively correlate with the company's performance, as many standardized information system solutions are available today (Aydiner S. et al., 2019). It could be concluded that company managers take risks in introducing new information systems, including business intelligence and data warehousing. Managers need to assess in detail all potential risks and examine potential scenarios.

Another research study (Ain N. et al., 2019) emphasizes that the successful introduction of business intelligence into companies is hindered by the mismatch between the results desired and the funds invested. Namely, the results do not meet the desired results if the system is not used to the full extent, or the users do not want to use the system, or if the business intelligence system has been introduced improperly or inefficiently. When assessing and introducing a business intelligence system into a company, the challenges that the user might face in exploiting the system should be taken into account. It could be concluded that the introduction of business intelligence and data warehousing provides benefits, as well as poses various risks.

\section{An examination of data warehousing and business intelligence implemented by the SJSC State Real Estate and the JSC Latvian State Forests}

To examine the benefits and challenges of applying data warehousing and business intelligence by a business, the research performed a case study on two companies: the SJSC "State Real Estate" and JSC "Latvian State Forests". At the beginning of the case study, the following aim of the study was defined: to examine the practices, benefits and challenges of data warehousing and business intelligence in Latvia. At the next stage of the case study, an interview protocol was developed, which included questions for company representatives in relation to data warehousing and business intelligence practices in their 
companies. Subsequently, semi-structured interviews with the company representatives were conducted. An analysis of secondary data was also performed as well as information available in the public space of Latvia and company annual reports were used to obtain information on the selected companies. As a result, the research analysed and interpreted the data obtained, as well as compared the experience of the companies in relation to data warehousing and business intelligence practices.

SJSC State Real Estate. The company is the largest land and building manager in Latvia, engaged in the management, alienation, leasing, administration and development of new nationally significant construction projects and the implementation of various real estate target projects. An analysis of the company's IT infrastructure reveals that the company constantly develops its internal information system architecture; besides, it uses information and data from data sources belonging to third parties, e.g. the State Land Service.

The company began considering introducing data warehousing together with business intelligence in 2018, as there was a need for an electronic data analysis and reporting solution. Before the business intelligence was introduced, the company did not have a unified reporting tool. Mostly MS Excel was used to process and connect data from various systems manually, perform calculations and other data analytics. The results obtained were exported to a final report, which could represent both a specially formatted MS Excel final document and an MS PowerPoint presentation. The company had and still has information systems with their own built-in reporting solutions. For example, the real estate management information system has been designed as a special data export tool by means of which the user can create a desired report in MS Excel format. A feasibility study of the company's information systems for the introduction of a reporting tool and business intelligence in 2018 found that the amount and complexity of data in the company's current information systems were large and high, and more attention should be paid to data quality assurance problems. Attention should also be paid to data integrity between systems, as well as ways should be sought to normalize data so that the data from several information systems are interoperable. As a result of the feasibility study, several business intelligence solutions were analysed and prototypes were developed: SAP BusinessObjects, Microsoft PowerBI and Qlik Sense. After assessing their advantages and disadvantages, Microsoft PowerBI was chosen by the company.

The company's data warehouse has been built according to the industry standard, i.e. from several data sources, using the ETL process; the data are loaded into a separate, permanent database, from which business intelligence reports are created afterwards. As prescribed by the industry standard, ordinary users are not expected to work with data warehousing technologies daily. This is the responsibility of the IT Department, project managers and an outsourced contractor. In the company, the business information system development department is responsible for business intelligence and data warehousing, yet not all employees of this department are constantly involved in business intelligence projects. Two information system project managers are most often involved in business intelligence and data warehousing projects - system analysts and one information systems administrator. It should be considered that the employees are not only involved in business intelligence and data warehousing projects but are also busy dealing with other IT projects. If necessary, other employees from the IT Department or employees from other departments are involved in dealing with specialized reports or solutions relating to a specific business process.

In the company, reports are mostly produced through outsourced services. For this purpose, the company has hired two partners who work with both data warehousing and business intelligence reports. Among the company's organisational units, only the IT Department produces its own reports for its own 
needs. Reports for the company are produced by the outsourced partners in cooperation with the company's project managers by employing Agile Project Management Methodology.

Since the company is a state joint stock company and the Ministry of Finance is a $100 \%$ shareholder, which means that if business intelligence solutions need to be outsourced, the company needs to invite tenders for a contract with a developer or buy working hours in the Electronic Procurement System (EIS).

The company supports sending employees to Microsoft PowerBI training, yet in practice only five employees from the IT and Financial Analysis Departments have been trained. The training is likely not popular due to the low popularity of the business intelligence tool used in the company, yet the employees do not want to undergo such training on their own initiative. However, any training request that the company has received from their employees regarding PowerBI have been approved by the company. In practice, to work with reports daily, no special training is required, and basic instructions of the IT Department are sufficient. However, detailed training is almost obligatory for independent reporting. The company has 75 PowerBI licenses that allow it to continuously produce reports and other business intelligence solutions, and the company's long-term plan is to provide PowerBI licenses to all its employees over time.

The company is still at the early stages of business intelligence. The first report using a data warehouse was prepared in the summer of 2018, which, according to an expert, was relatively recently. Preparing the report took less than two months from the start of the project to the delivery of the final product. The company has already developed over 20 various business intelligence reports or business intelligence solutions. Overall, the expert rated the business intelligence tool used in the company as quite unpopular because there was a certain reluctance to develop in the information technology industry, especially among the employees. The users of the tool also often do not understand the nature of business intelligence and the results to be achieved and often use business intelligence solutions as an additional tool. Instead of taking full advantage of all the features available in the business intelligence tool, its users export any report to an MS Excel file and work with it in MS Excel. This is one of the most serious problems that hinder the development of business intelligence in the company.

JSC Latvian State Forests. The core business of the company is forestry, and it is also the company's main source of revenue. The company is also engaged in hunting and supplying recreation services, produces selected seeds and seedlings, as well as offers underground resources in the market: sand, gravel and peat. The company has 1200 employees. The company spends a lot of funds on maintaining its information systems and subscribing to databases, and in 2018 the total expenditure reached EUR 1.83 million.

The company actively applies business intelligence together with data warehousing. The company began introducing business intelligence in 2012 because of the need for an electronic, automated reporting tool. Until then, no basic and support process reporting solution was available in the company, and everything was done manually by using MS Excel. Given the company's information system infrastructure at the time, based on a feasibility study the company chose a Microstrategy business intelligence solution, which was launched in 2012. Today too Microstrategy is the company's main and only business intelligence solution.

The data warehouse of the JSC Latvian State Forests has been created according to the industry standard, i.e. from several data sources, using the ETL process; the data are loaded into a separate, permanent database, from which business intelligence reports are created afterwards. The company's employees are not expected to work with data warehousing technologies daily, as this is the responsibility of the respective project management team and outsourced contractors. 
The company has a separate project team for business intelligence, which consists of three employees: a business intelligence project manager, a systems analyst and an IT administrator. All the employees work on only business intelligence and data warehousing solutions. Reports for the company are produced by both outsourced developers and the company's own employees. The outsourced developers usually produce the most complex reports, which require more complex visualizations or more complex data sources, while the company's employees produce reports from one data source, which require simpler visualizations. For this purpose, the project management team answers questions and offers help on applying Microstrategy. The company has distributed a total of 260 Microstrategy licenses to the users.

The project management team for business intelligence also helps the users with reporting technologically (in relation to data warehousing). If a user wants to produce a new report or other solution, $\mathrm{s} /$ he turns to a project manager or the responsible employee with a request to provide the data to the user. The responsible employee examines the request and gives the user access to the data. This means that the responsible employee connects the data warehouse with the business intelligence application (Microstrategy) so that the user can successfully produce a report. If the data needed by the user are not available, the responsible employee offers other data or other ways to achieve the result needed. Agile Project Management Methodology is used for reports and solutions that require outsourcing. The project manager submits the technical and functional requirements to an outsourced developer, and after each iteration of the business intelligence solution, the project manager provides feedback until the result is achieved. A contract with developers is concluded in accordance with the provisions of the Public Procurement Law.

Users independently develop reports and other solutions based on data from various data sources. In the company, the main data sources are the geospatial information system as well as the accounting information system. In addition, reports are produced based on data from the information systems of personnel management and cooperation partners. Namely, all the above systems are loaded into the data warehouse. In some cases, users use their personal data sources (such as XLS files), yet the company seeks to train the users for the best practices of data warehousing and business intelligence to produce reports, if possible, based on data from the data warehouse.

Although any employee of the company who is provided with a license and training theoretically has an opportunity to produce business intelligence reports, the company has departments that produce relatively more reports. Most reports are produced by the departments related to production, logging, planning and timber supply. The company's Financial Management Department with its business intelligence reports related to finance are also among the leaders.

The company provides its employees with training in applying the business intelligence application Microstrategy. All the employees who are supposed to work with Microstrategy and related systems daily are sent to training. In the company, however, the users do not have complete confidence in new IT solutions, including data warehousing and business intelligence. The company's employees needed to be actively convinced of the value added of business intelligence and its opportunities, yet overall, according to the expert, there was a tendency for the employees to develop and learn. Often the other extreme was that the results expected by the users from the business intelligence application were too high. The company's management actively supported business intelligence projects.

The expert admitted that the company also had a data quality problem - due to data imperfections, the company had problems with introducing and maintaining data warehousing and business intelligence solutions. This was due to the shortcomings of previously introduced information systems, as well as a lack of user training in using the systems. However, the company actively works on it, and the overall data 
quality situation improves. The company develops specific data warehousing solutions that help to eliminate the problems in real time or notify those responsible of an existing or potential problem.

Table 1

Characteristics of applying data warehousing and business intelligence by the SJSC State Real Estate and the JSC Latvian State Forests

\begin{tabular}{|c|c|c|}
\hline Indicator & $\begin{array}{l}\text { SJSC State Real } \\
\text { Estate }\end{array}$ & JSC Latvian State Forests \\
\hline $\begin{array}{l}\text { Data warehousing and business } \\
\text { intelligence implemented }\end{array}$ & Since 2018 & Since 2012 \\
\hline $\begin{array}{l}\text { Reason for introducing data } \\
\text { warehousing and business intelligence }\end{array}$ & \multicolumn{2}{|c|}{ Need for an electronic reporting tool } \\
\hline $\begin{array}{l}\text { Solution used before business } \\
\text { intelligence and data warehousing have } \\
\text { been introduced }\end{array}$ & \multicolumn{2}{|c|}{ No, standard office applications } \\
\hline $\begin{array}{l}\text { Responsible employees working with } \\
\text { data warehousing and business } \\
\text { intelligence }\end{array}$ & $\begin{array}{l}\text { Two information system } \\
\text { project managers, } \\
\text { systems analysts; } \\
\text { information systems } \\
\text { administrator; Business } \\
\text { Reporting and Analysis } \\
\text { Department }\end{array}$ & $\begin{array}{l}\text { Project management team } \\
\text { (a business intelligence } \\
\text { project manager, a systems } \\
\text { analyst, an IT } \\
\text { administrator) and } \\
\text { outsourced contractors }\end{array}$ \\
\hline $\begin{array}{l}\text { Employees who produce reports for the } \\
\text { company }\end{array}$ & $\begin{array}{l}\text { Outsourcing, less often } \\
\text { - company employees }\end{array}$ & $\begin{array}{l}\text { Company employees, for } \\
\text { complex reports - } \\
\text { outsourcing }\end{array}$ \\
\hline Business intelligence tool & Microsoft PowerBI & Microstrategy \\
\hline Data warehouse architecture & \multicolumn{2}{|c|}{ Standard } \\
\hline Business intelligence tool licenses & 75 & 260 \\
\hline $\begin{array}{l}\text { Number of licenses versus the number of } \\
\text { employees }\end{array}$ & $\begin{array}{c}(523 \text { vs } 75) \\
6.97\end{array}$ & $\begin{array}{c}(1200 \text { vs } 260) \\
4.61\end{array}$ \\
\hline $\begin{array}{l}\text { Departments that use data warehousing } \\
\text { and business intelligence }\end{array}$ & $\begin{array}{c}\text { Finance Department, } \\
\text { Real Estate } \\
\text { Management and } \\
\text { Maintenance } \\
\text { Department, Real } \\
\text { Estate Leasing and } \\
\text { Sales Department }\end{array}$ & All company departments \\
\hline $\begin{array}{l}\text { Data quality problems identified in the } \\
\text { company }\end{array}$ & $\begin{array}{l}\text { Significant data quality } \\
\text { problems }\end{array}$ & $\begin{array}{l}\text { Insignificant data quality } \\
\text { problems }\end{array}$ \\
\hline $\begin{array}{l}\text { Employees' desire to learn new } \\
\text { information technologies }\end{array}$ & \multicolumn{2}{|c|}{ Moderate - low } \\
\hline $\begin{array}{l}\text { Company management support for } \\
\text { business intelligence and data } \\
\text { warehousing projects }\end{array}$ & \multicolumn{2}{|c|}{ Significant } \\
\hline $\begin{array}{l}\text { Methodology applied to managing } \\
\text { business intelligence and data } \\
\text { warehousing projects }\end{array}$ & \multicolumn{2}{|c|}{ Agile } \\
\hline
\end{tabular}

Source: authors' own compilation based on expert interview results

It could be concluded that in the JSC Latvian State Forests, business intelligence and data warehousing are relatively advanced, as well as both technologies are used in accordance with the principles of good practice. The users of the technologies generally understand how the tools work and how to use them. The 
application of business intelligence in the company expands, yet it is somewhat hampered by shortcomings in data quality.

It could be concluded that the experience of the companies in implementing the systems is different, yet it should be considered that the companies are engaged in different kinds of economic activity. The JSC Latvian State Forests can develop various, relatively simple business intelligence reports on and solutions to its core business, retrieving data only from its own information systems. However, in order to produce a high-quality report, the SJSC State Real Estate needs data from several cooperation partners, e.g. the State Land Service, the Ministry of Finance etc.

Overall, the experts rated the implementation of business intelligence and data warehousing in both companies positively, as it provided several benefits. For example, in the case of the SJSC State Real Estate, the automated reporting process replaces a personnel member and speeds up the flows of information between the organizational units from a few days to a few minutes. The expert of the JSC Latvian State Forests also acknowledged the value added of the technologies, as the employees are able to optimize their work through producing no MS Excel reports, and since manual work is excluded, they can go into the details of the reports.

Before business intelligence and data warehousing were introduced, both companies did not have a specific system for reporting from other information systems. The largest difference lies in the fact that the JSC Latvian State Forests introduced business intelligence together with data warehousing six years earlier than the SJSC State Real Estate did. This is also the main reason why both systems are more advanced at the JSC Latvian State Forests. The companies have also introduced various business intelligence solutions. Microstrategy was one of the most popular solutions in 2012, as well as it fully supported the infrastructure of the JSC Latvian State Forests. PowerBI, however, appeared in the market only in 2015. PowerBI is a Microsoft product and at the time of introducing business intelligence, the information system architecture of the SJSC State Real Estate was based on Microsoft products; therefore, the company's choice to introduce PowerBI was logical.

The companies have similar business intelligence and data warehousing teams, yet it should be mentioned that the team of the JSC Latvian State Forests deals only with business intelligence projects, while the respective team of the SJSC State Real Estate also deals with other IT projects and does not spend as much time on business intelligence and data warehousing as it should, which has significantly affected the development of business intelligence and data warehousing at the company.

A significant difference between the companies lies in the application of business intelligence among the company's employees. The JSC Latvian State Forests' business intelligence tool is very popular, as well as the users are able to use this tool independently. In contrast, the majority of reports in the SJSC State Real Estate are produced with the help of its cooperation partners - after submitting the specifications, the outsourced programmer produces a report.

\section{Scenarios for applying data warehousing and business intelligence by companies}

The scenarios were designed after examining the relevant literature and consulting with experts in the companies. It should be noted that the scenarios were mainly focused on the company profile described large companies (250+ employees) having information systems, their own IT specialists, financial analysts and business intelligence together with data warehousing introduced. The scenarios were based on two main criteria: control of technological and administrative processes (implemented by the company itself or outsourced, respectively). 
Scenario 1: Replacing data warehousing and business intelligence with standardized information system solutions. This scenario requires the company not to introduce any business intelligence and data warehousing technologies, instead the company need to replace the features provided by the technologies with standard office software, such as Microsoft Office or LibreOffice. Microsoft Office is the most popular office software package in the world, it contains all the programs necessary for office work, incl. MS Excel, which is also designed for various kinds of data analysis. Employing the software's built-in features, the users are able to produce various kinds of reports, make data visualizations, as well as retrieve data from external data sources. Accordingly, if this scenario is implemented, the company would not have to spend financial resources on introducing and maintaining business intelligence and data warehousing solutions, as largest companies already use an office software package. Applying business intelligence tools would not require additional training for the company's employees, and the company's IT Department would not have additional work responsibilities to maintain or introduce the technologies.

Scenario 2: Business intelligence and data warehousing as an outsourced service. According to this scenario, the company outsources all technological and project management work related to business intelligence and data warehousing. In this way, the company does not have to worry about the technological aspects of business intelligence and data warehousing, as all project management work and business intelligence reporting and application development work for the company are performed by one or more outsourced service providers.

According to the scenario, the company would entrust its business intelligence and data warehousing solutions to professionals who would introduce the technology according to the principles of good practice, as well as it would relieve the current IT personnel. The company should only consider creating and promoting the demand for new reports and solutions in the company. Accordingly, all technological and administrative processes would be almost entirely outsourced. The scenario assumes that the company purchases outsourced working hours over a one-year period, which is equivalent to one full-time business intelligence solution developer. Accordingly, the company can purchase more working hours if needed. To calculate the cost of implementing the scenario, it was assumed that the company would outsource one full-time business intelligence and data warehousing specialist. This assumption was based on the intensity of using business intelligence and data warehousing outsourcing by the SJSC State Real Estate. In addition, the calculation assumed the use of Microsoft PowerBI, the market leader in business intelligence tools, with a monthly license of EUR 8.40 per user and a license for all 250 employees. The total cost of implementing the scenario equals EUR 146321 (including EUR 121121 per year for a full-time developer and EUR 25200 per year for the provision of business intelligence tools to 250 employees). The costs could increase if the company chooses to purchase more developer working hours, or purchase more business intelligence tool licenses.

Scenario 3: Adapting personnel positions to business intelligence and data warehousing. This scenario involves creating new or reorganizing current jobs in the company to include specially trained data analytics specialists whose main task is to produce business intelligence reports. This scenario also involves creating new or reorganizing current jobs to have additional IT specialists whose main task would be to create integrations (creation of a new data area) for analysts, as well as perform other business intelligence and data warehouse maintenance work.

One of the easiest ways for a company to ensure the implementation of this scenario is to train the current employees for business intelligence and data warehousing technologies. For example, in the case of the SJSC State Real Estate, a current financial analyst needs to go on a course on professional business intelligence tools a current IT specialist needs to go on a course on database technologies. Accordingly, the 
employees would need to cooperate with each other to develop new business intelligence reports and solutions daily. The company should consider relieving the employees of other work tasks not related to business intelligence or data warehousing, thereby keeping at least two employees who work exclusively with these technologies.

To implement this scenario, the company should spend additional resources on hiring new employees or training the current employees. If the employees are also relieved of other job responsibilities, the company need to redistribute the jobs. The scenario assumes that the company provides a separate job position for producing business intelligence reports and maintaining the database. If necessary, the company can assign more employees to the tasks.

To calculate the costs of implementing the scenario, it was assumed that the company would hire a data analytics specialist with a gross wage of EUR 1224 per month. The wage was determined taking into account the average wage of a business analyst paid in several national companies. The calculation assumed the use of Microsoft PowerBI - the market leader in business intelligence tools -, a monthly license of which costs EUR 8.40 per user, and the license is provided to all 250 employees. Accordingly, the total cost of the third scenario amounts to EUR 43430.64 (EUR 18230.64 per year for a full-time business intelligence specialist and EUR 25200 per year for the provision of business intelligence tools to 250 employees). The costs could increase if the company chooses to hire more business intelligence professionals or purchase more business intelligence tool licenses. Other additional costs related to the recruitment of employees should also be taken into account, e.g. holidays, bonuses, office expenses etc.

During the interviews with experts from the companies included in the case study, it was established that the SJSC State Real Estate viewed this scenario as its primary one, as well as it could be concluded that the company was partially in the process of implementing this scenario. As found in the case study, one of the peculiarities of the SJSC State Real Estate regarding data warehousing and business intelligence was that most of its reports were outsourced, which required significant financial resources for the company. This scenario would allow the company to develop its data culture, as well as save on the development of business intelligence reports and solutions. One aspect that hindered the implementation of this scenario is that the company's specialists were burdened with other daily tasks or projects, and the company had no plans to hire additional personnel. This means that in fact the workload for the specialists and the respective departments would only increase. In addition, this scenario would not solve the problem of poor e-skills in the company.

In the case of the JSC Latvian State Forests, this scenario has already been implemented. The company's IT specialists, at the request of other employees, already create specialized data sets that may be used by the company's employees. The company's Data and Financial Analysis Department is a user of high-level business intelligence. From a business intelligence technology management perspective, this is the most convenient option because centralized reporting control is assigned to one or a few employees. Another way to adapt this scenario to the needs of the JSC Latvian State Forests is to establish a special separate organisational unit that deals only with reporting requests made by employees, enabling any employee to produce business intelligence reports. However, in the foreseeable future, the company is not considering completely abandoning outsourcing.

\section{Conclusions and proposals}

1) Business intelligence and data warehousing are a set of technologies that, in parallel with other information systems used by the company, perform analytics of the company's internal data and automation of various work tasks in the company. The most significant benefits of introducing business 
intelligence and data warehousing are automatic reporting using the company's internal data, automation of various core business and support processes, as well as acquisition of new information for business decision making. The most significant challenges are as follows: employees with advanced e-skills are needed, employees need to motivated to use the technologies, as well as the quality of data in the company.

2) The case study on the JSC Latvian State Forests and the SJSC State Real Estate allowed concluding that the companies had a relatively complex IT architecture with many information systems. Both companies had implemented business intelligence together with data warehousing in accordance with the industry standard; however, there were differences in applying business intelligence between the companies. First of all, the business intelligence of the JSC Latvian State Forests was more advanced than that of the SJSC State Real Estate, as the company had several users of business intelligence and more successful business intelligence solutions. In addition, the JSC Latvian State Forests had more business intelligence solutions related to its core business, as well as the company invested more in employee training in applying business intelligence.

3) The case study found that in a company, the business intelligence system can make its core business and support processes faster and cheaper or require less human resources. However, challenges were identified regarding a lack of motivation in employees to learn new technologies. The companies that control their technological and administrative processes related to business intelligence and data warehousing as much as possible can more successfully apply the mentioned technologies. The most important factor affecting the application of the technologies is the willingness of employees to use and learn how to use such technologies.

4) The scenario analysis revealed that large companies should perform as many administrative and technological processes related to the mentioned technologies as possible themselves rather than outsource them. This allows a company to save funds on the development of such technologies and improve the company's data culture. Outsourcing the service for one year would cost a company EUR 146321 per year. However, if a company has its own specialist, it would cost EUR 43430.64 per year. Accordingly, the hypothesis put forward in the research proved to be true, i.e. introducing a business intelligence information system and data warehousing into a company is more economically advantageous if using only the human resources available in the company.

\section{Bibliography}

1. Ain, N., Vaia G., DeLone, W.H., Waheed, M. (2019). Two Decades of Research on Business Intelligence System Adoption, Utilization and Success - A Systematic Literature Review. Decision Support Systems, Volume 125, pp. 1-13.

2. Aydiner, A.S., Tatoglu, E., Bayraktar, E., Zaim, S. (2019). Information System Capabilities and Firm Performance: Opening the Black Box through Decision-making Performance and Business-process Performance. International Journal of Information Management, Volume 47, August, pp. 168-182.

3. Bach, M.P., Celjo, A., Zoroja, J. (2016). Technology Acceptance Model for Business Intelligence Systems: Preliminary Research. Procedia Computer Science, Volume 100, pp. 995-1001.

4. Bozic, K., Dimovski, V. (2019). Business Intelligence and Analytics Use, Innovation Ambidexterity, and Firm Performance: A Dynamic Capabilities Perspective. The Journal of Strategic Information Systems, Volume 28, Issue 4, December, pp. 1-20.

5. Disteina, I. (2019). Implementing a Business Intelligence Solution for a Car Sale Company. Riga: Riga Technical University. p. 127.

6. Ezerins, I. (2009). Data Warehousing - from IT to Business. Riga: University of Latvia. p. 71.

7. Grubljesic, T., Jaklic, J. (2015). Conceptualization of the Business Intelligence Extended Use Model. Journal of Computer Information Systems, Volume 55, Issue 3, pp. 72-82.

8. Harrison, R., Parker, A., Brosas, G., Chiong, R., Tian, X. (2015). The Role of Technology in the Management and Exploitation of Internal Business Intelligence. Journal of Systems and Information Technology, Volume 17, Issue 3, pp. 247-262. 
9. Kimball, R., Ross, M., Thornthwaite, W., Mundy, J., Becker, B. (2006). The Data Warehouse Lifecycle Toolkit. USA: Wiley Publishing. p. 672.

10. Larson, D., Chang, V. (2016). A Review and Future Direction of Agile, Business Intelligence, Analytics and Data Science. International Journal of Information Management, Volume 36, pp. 700-710.

11. Peskops, M. (2017). Biznesa inteligences sistemu piedavato funkciju izmantosana konkuretspejas veidosana (Use of Functions Offered by Business Intelligence Systems in Creating Competitiveness). Riga: University of Latvia. p. 87.

12. Presthus, W., Stian, S. (2015). The Secret of My Success: An Exploratory Study of Business Intelligence Management in the Norwegian Industry. Procedia Computer Science, Volume 64, pp. 240-247.

13. Raza, B., Aslam, A., Sher, A., Malik, A.K., Faheem, M. (2020). Autonomic Performance Prediction Framework for Data Warehouse Queries Using Lazy Learning Approach. Applied Soft Computing, Volume 91, June, pp. 106216.

14. Wieder, B., Ossimitz, M.L. (2015). The Impact of Business Intelligence on the Quality of Decision Making - a Mediation Model. Procedia Computer Science, Volume 64, pp. 1163-1171. 